\title{
PENALARAN MORAL DAN PERILAKU KECURANGAN AKADEMIK MAHASISWA YANG SEDANG MENGERJAKAN SKRIPSI
}

\author{
Zenitha Putri Buana ${ }^{1}$ \\ Fakultas Psikologi, Prodi Studi Psikologi, Universitas Kristen Satya Wacana \\ Christiana Hari Soetjiningsih ${ }^{2}$ \\ Fakultas Psikologi, Prodi Studi Psikologi, Universitas Kristen Satya Wacana \\ soetji_25@yahoo.co.id
}

\begin{abstract}
This research was aimed to find out the correlation between moral reasoning and academic cheating behavior on students who are working on their thesis. The number of participants in this study were the students class of 2014 as many as 109 students, Faculty of Psychology, Universitas Kristen Satya Wacana (UKSW) with data collection techniques using purposive sampling. Moral reasoning variable were measured with Defining Issues Test (DIT) I scale and academic cheating behavior measured with scale made by researchers based on the aspect's as cheating, fabrication, facilitating academic dishonesty, and plagiarism. Analysis data using Spearman's Rho correlation technique. acquired correlation coefficient is $r=0,003$ with significant $0,489(p>0,05)$ it can be concluded there is no significance relationship between moral reasoning with academic cheating behavior on Psychology students force 2014. at Satya Wacana Christian University.

Keyword: academic cheating behavior, moral reasoning, student.
\end{abstract}

\begin{abstract}
Abstrak
Penelitian ini bertujuan untuk menentukan hubungan antara penalaran moral dengan perilaku kecurangan akademik pada mahasiswa sedang mengerjakan tugas akhir/skripsi. Jumlah partisipan sebanyak 109 mahasiwa angkatan 2014 yang sedang mengerjakan tugas akhir/skripsi Fakultas Psikologi Universitas Kristen Satya Wacana (UKSW) yang diperoleh dengan teknik purposive sampling. Variabel penalaran moral diukur dengan skala Defining Issues Test (DIT) 1 dan variabel kecurangan akademik diukur dengan skala yang dibuat oleh peneliti berdasarkan aspek-aspek yang terdiri dari kecurangan, fabrikasi, memfasilitasi ketidakjujuran akademis, dan plagiarisme. Analisis data menggunakan teknik korelasi Spearman's Rho menunjukkan hasil koefisien korelasi (r) sebesar 0,003 dengan nilai signifikansi sebesar $0,489(\mathrm{p}>0,05)$ yang berarti tidak ada hubungan signifikan antara penalaran moral dan perilaku kecurangan akademik mahasiswa yang sedang mengerjakan skripsi.

Kata kunci: kecurangan akademik, mahasiswa, penalaran moral.
\end{abstract}




\section{PENDAHULUAN}

Dunia pendidikan terutama di tingkat pendidikan tinggi/universitas, identik dengan adanya pemberian tugas-tugas dan tes/ujian kepada mahasiswanya dengan tujuan untuk mengukur tingkat prestasi sebagai hasil usaha yang telah dicapai oleh mahasiswa. Selain itu ada tugas yang masih ditakuti oleh banyak mahasiswa yaitu pembuatan tugas akhir/skripsi. Namun saat ini banyak mahasiswa yang melakukan perilaku yang tidak terpuji pada saat mengerjakan skripsi, tes/ujian dan dalam menyelesaikan tugas-tugas perkuliahan dari dosen. Dari sepuluh mahasiswa yang penulis wawancarai, enam mahasiswa mengaku dalam mengerjakan tugas dosen mereka sering melakukan jalan pintas dengan cara menyontek, melihat, dan menyalin pekerjaan mahasiswa lainnya. Selain itu, mereka sering bertindak curang dalam mengerjakan tes/ujian seperti melihat/menyalin jawaban teman lain, plagiasi, atau membuka smartphone untuk mencari jawaban di internet. Hal tersebut merupakan beberapa contoh perilaku kecurangan akademik. Perilaku kecurangan akademik saat ini sudah menjadi fenomena yang memprihatinkan khususnya di tingkat perguruan tinggi dan saat ini nampaknya menjadi hal yang biasa dilakukan, namun masih kurang mendapat perhatian dan penanganan yang serius dari pihak-pihak tertentu.

Gehring dan Pavela (1994) mendefinisikan kecurangan akademik sebagai tindakan penipuan yang disengaja, di mana seseorang berusaha untuk mengklaim pekerjaan atau usaha orang lain tanpa izin, atau menggunakan materi yang tidak sah dan informasi palsu dalam setiap tugas akademis. Ketidakjujuran akademis juga mencakup pemalsuan dokumen akademik, dengan sengaja menghambat atau merusak karya akademis orang lain, atau membantu mahasiswa lain dalam tindakan ketidakjujuran. Menurut Gehring dan Pavela (1994) kecurangan akademik mencakup (1) Kecurangan: sengaja menggunakan atau mencoba menggunakan bahan, informasi, atau alat bantu belajar yang tidak sah dalam latihan akademis, (2) Fabrikasi: pemalsuan yang disengaja dan tidak sah atau penemuan informasi atau kutipan dalam tugas akademis, (3) Memfasilitasi ketidakjujuran akademis: sengaja atau dengan sengaja membantu atau mencoba menolong orang lain untuk melakukan tindakan ketidakjujuran akademik. (4) Plagiarisme: sengaja atau secara sengaja mengkutip kata-kata orang lain sebagai milik seseorang dalam tugas akademis.

Ada berbagai faktor yang dapat memengaruhi terjadinya kecurangan akademik. Faktor-faktor yang mempengaruhi kecurangan akademik antara lain konsep diri akademik yang rendah ( Ningsih \& Pratikto, 2012), self-efficacy dan penalaran moral (Anderman \& Murdock, 2007; Putri \& Dewi, 2018), serta religi (Rettinger \& Jordan, 2005). Penalaran moral adalah proses 
berpikir yang berkaitan dengan aturan dan konvensi tentang apa yang seharusnya dilakukan oleh manusia dalam interaksinya dengan orang lain (Kohlberg dalam Santrock, 2002). Selanjutnya Kohlberg menekankan bahwa penentu kematangan moral individu adalah cara individu bernalar, bukan kandungan individu dalam merespons. Penalaran moral adalah proses berpikir yang berkaitan dengan aturan dan konvensi tentang apa yang seharusnya dilakukan oleh manusia dalam interaksinya dengan orang lain. Artinya fokus dari penalaran moral ini terletak pada pola pikir khususnya berpikiran logis dalam mempertimbangkan suatu hal yang digunakan oleh setiap manusia untuk membenarkan sebuah keputusan moral (dalam Santrock, 2002). Menurut Soetjiningsih (2017) mahasiswa yang dari segi tahapan perkembangan berada pada tahap remaja akhir seharusnya dari segi penalaran moral menurut Kohlberg minimal sudah sampai pada tahapan perkembangan moral konvensional. Tahap ini menekankan adanya pemahaman menjadi pribadi yang baik yang pada dasarnya berarti memiliki motif-motif yang bisa membantu hubungan yang baik antar pribadi, juga memelihara tatanan sosial masyarakat dengan mematuhi hukum, keputusan, dan kovensi sosial.

Berkaitan dengan pengerjaan tugas, penulis juga mengobservasi dan mewawancarai beberapa mahasiswa S1 Psikologi UKSW yang sedang mengambil skripsi/tugas akhir. Hasil menunjukkan empat dari enam mahasiswa melakukan kecurangan seperti mengutip kalimat sebagian atau seluruh kalimat tanpa menyertakan sumber yang jelas, memalsukan daftar pustaka, memalsukan tahun dan volume jurnal, serta meng copy-paste tulisan dalam skripsi/tugas akhir mahasiswa lain.

Penelitian yang dilakukan oleh Nursalam, Bani, dan Munirah (2013) menghasilkan temuan bahwa mayoritas anak didik menyatakan pernah melakukan kecurangan akademik dalam bentuk menyontek ketika masih sekolah atau kuliah, beberapa diantaranya bahkan ditemukan adanya tugas akhir (skripsi) mahasiswa yang mengindikasi adanya praktik plagiarism dari karya tulis orang lain. Studi lainnya dari Broeckelman \& Pollock (2006) melaporkan bahwa frekuensi plagiarisme, kecurangan, dan bentuk ketidakjujuran akademik lainnya di institusi pendidikan mengalami peningkatan dari tahun ke tahun. Dari penelusuran beberapa jurnal hasil penelitian menunjukkan perkiraan proporsi mahasiswa yang melakukan kecurangan akademik makin meningkat dan terjadi di banyak kampus (McCabe., 2005). Demikian pula kabar yang dilansir dari cnn.indonesia 2017 menyebutkan seorang mahasiswa doktoral di Technische Universiteit Delft Belanda, Dwi Hartanto, diketahui berbohong mengenai prestasinya di bidang antariksa. Dwi Hartanto disebut-sebut memalsukan dokumen klarifikasi sepanjang 5 halaman, yang dimuat pada sebuah situs. 
Riset-riset sebelumnya berkaitan dengan penalaran moral dan perilaku kecurangan akademik yang dilakukan oleh Khoridatul (2014) didapatkan hasil tidak ada korelasi antara penalaran moral dengan perilaku kecurangan mencontek. Penelitian lain oleh Veronikha, Yusuf dan Machmuroch (2013) menghasilkan temuan bahwa ada hubungan yang negatif antara moral judgment maturity dengan perilaku mencontek. Penelitian Budinugroho (2006) mendapatkan hasil ada hubungan yang positif antara penalaran moral dan perilaku kecurangan akademik. Ravenscroft dan Shrader (2004), menunjukkan hasil bahwa tidak ada hubungan antara penalaran moral dan kejujuran, namun tingkat kecurangan yang tinggi terkait dengan tindak kejujuran yang rendah. Peneliti lain Belanger, Leonard, dan LeBrasseur (2012) menemukan bahwa penilaian moral dan kejujuran tidak terkait, namun tingkat kecurangan yang tinggi terkait dengan kurangnya kejujuran.

Dari pemaparan diatas maka penulis tertarik untuk meneliti topik tentang penalaran moral dan perilaku kecurangan akademik karena fenomena tersebut menjadi masalah yang urgent di institusi akademik dan adanya perbedaan hasil penelitian yang di dapat. Mahasiswa yang dari segi usia seharusnya penalaran moralnya sudah mampu memahami perilaku yang benar-salah dan yang salah seharusnya tidak dilakukan, namun pada kenyataannya masih melakukan kecurangan akademik. Penelitian ini bertujuan untuk menguji hubungan penalaran moral dengan perilaku kecurangan akademik pada mahasiswa psikologi Universitas Kristen Satya Wacana angkatan 2014. Partisipan penelitian adalah mahasiswa angkatan 2014 karena pada saat penelitian ini dilaksanakan, jumlah mahasiswa terbanyak yang sedang mengambil mata kuliah skripsi adalah mahasiswa angkatan 2014. Manfaat penelitian ini, secara teoritis menambah informasi tentang kaitan antara penalaran moral dan kecurangan akademik di kalangan mahasiswa, dan mafaat praktisnya adalah sebagai masukan bagi lembaga pendidikan dalam upaya untuk mengatasi kecurangan akademik. Selain itu dapat menjadi referensi untuk penelitian yang berkaitan dengan penalaran moral dan kecurangan akademik bagi peneliti berikutnya.

Hipotesis penelitian yaitu ada hubungan negatif antara penalaran moral dan kecurangan akademik pada mahasiswa yang sedang mengambil skripsi. Makin tinggi penalaran moral mahasiswa maka makin rendah kecurangan akademiknya, dan sebaliknya makain rendah penalaran moral maka makin tinggi kecurangan akademiknya. 


\section{METODE}

Jenis penelitian ini adalah penelitian kuantitatif dengan desain korelasional untuk menentukan hubungan antara penalaran moral dengan perilaku kecurangan akademik pada mahasiswa S1 Psikologi Universitas Kristen Satya Wacana angkatan 2014.

Variabel Penelitian

Variabel Independen : Penalaran Moral

Variabel Dependen : Kecurangan Akademi

Penentuan partisipan penelitian menggunakan teknik purposive sampling dengan kriteria mahasiswa S1 Psikologi UKSW angkatan 2014, status aktif (melakukan registrasi), dan mengambil mata kuliah Skripsi/Tugas Akhir. Dengan kriteria tersebut, data yang diperoleh dari Bagian Kemahasiswaan ada 165 mahasiswa. Dalam proses pengumpulan data, sebanyak 9 mahasiswa sulit ditemui dan data dari 47 mahasiswa dinyatakan gugur karena datanya tidak memenuhi syarat untuk skoring, sehingga total ada 109 partisipan yang datanya dapat diolah. Metode Pengumpulan Data

Skala Perilaku Kecurangan Akademik

Skala kecurangan akademik dalam penelitian ini dibuat oleh peneliti berdasarkan aspek-aspek yang dikemukakan oleh Pavella (1994) yaitu: kecurangan, fabrikasi, memfasilitasi ketidakjujuran akademis, plagiarisme. Total terdiri dari 30 aitem pernyataan dan terbagi menjadi 2 jenis aitem favorable dan unfavorable. Skala disajikan dalam bentuk skala Likert menggunakan 4 alternatif jawaban yaitu Sangat Sesuai (SS), Sesuai (S), Tidak Sesuai (TS), dan Sangat Tidak Sesuai (STS).

Hasil uji daya diskriminasi aitem dan reliabilitas skala kecurangan akademik yang berjumlah 30 aitem, didapatkan 1 aitem yang gugur dengan perhitungan 2 kali putaran karena memiliki nilai koefisien korelasi aitem yang lebih kecil dari 0,30 (Azwar, 2012). Jadi jumlah aitem menjadi 29 aitem dengan koefisien korelasi aitem totalnya bergerak antara 0,309-0,636 dengan nilai reliabilitas Alpha Cronbach sebesar 0,916 yang berarti skala memiliki reliabilitas yang baik (Azwar, 2012).

Skala Penalaran Moral

Skala Penalaran Moral mengacu teori penalaran moral dari Kohlberg yang dikembangkan oleh Rest (Rest, Narvaez, Thoma, \& Bebeau, 1997) yaitu Defining Issues Test (DIT). Skala ini dikemas dalam bentuk cerita dilema moral dimana terdapat 5 cerita yang masing-masing cerita berisi 12 aitem pernyataan moral. Dalam penelitian ini digunakan DIT 1 versi singkat dimana peneliti hanya menggunakan 3 cerita yaitu cerita Obat (Heinz and the Drug), Narapidana yang 
Melarikan Diri (Escaped Prisoner), dan Koran Sekolah (Newspaper). Penggunaan DIT versi singkat bertujuan untuk menghindari kejenuhan partisipan dan dapat mempersingkat waktu pelaksanaan pengisian kuesioner. Dari 12 pernyataan tersebut partisipan diminta untuk memilih salah satu dari lima pilihan jawaban yang disediakan, yaitu Amat Sangat Penting (ASP), Sangat Penting (SP), Penting (P), Kurang Penting (KP), dan Tidak Penting (TP). Selanjutnya subjek mengurutkan empat pernyataan terpenting pertama sampai dengan keempat yang harus dipertimbangkan untuk memutuskan masalah sosial tersebut. Kemudian dilakukan skoring dengan proses sebagai berikut :

Tabel 1

Lembar skoring data untuk setiap subjek

\begin{tabular}{|c|c|c|c|c|c|c|c|c|}
\hline Cerita & & & & & & & & \\
\hline & 2 & 3 & 4 & $5 \mathrm{~A}$ & 6 & $\bar{A}$ & $\mathrm{M}$ & $\mathrm{F}$ \\
\hline I & & & & & & & & \\
\hline II & & & & & & & & \\
\hline III & & & & & & & & \\
\hline Total & & & & & & & & \\
\hline
\end{tabular}

Pada tabel di atas dapat dilihat adanya tahap-tahap perkembangan moral, namun terdapat juga skor A, M, dan P. Nilai A menunjukkan orientasi anti kemapanan (antiestablishmen orientation), suatu pandangan yang mencela tradisi, dan menampilkan aturan sosial semaunya sendiri. Umumnya nilai A diabaikan dalam skoring DIT. Nilai $M$ adalah nilai yang menunjukkan pernyataan yang sama sekali tidak ada hubungannya dengan cerita dilema moral. Nilai $\mathrm{P}$ adalah nilai indeks dari suatu perkembangan moral.

Sebelum melakukan skoring penulis melihat konsistensi lembar jawaban partisipan dengan langkah-langkah berikut:

1) Maksimal terdapat delapan ketidak konsistenan jawaban dalam satu kasus, lebih dari itu akan dianggap gugur.

2) Melihat skor M dari responden, tidak boleh lebih dari 4.

3) Melihat jumlah jawaban yang sama. Jawaban yang sama pada setiap cerita tidak boleh lebih dari 9 jawaban. Apabila hal tersebut terjadi maka lembar jawab partisipan dianggap gugur.

Melihat pada tahap berapa $(2,3,4,5 \mathrm{~A}, 5 \mathrm{~B}, 6, \mathrm{~A}, \mathrm{M})$ masing-masing keempat urutan paling penting pertama, kedua, ketiga sampai keempat dengan melihat tabel penilaian penalaran moral berikut : 
Tabel 2

Penilaian Penalaran Moral

\begin{tabular}{|c|c|c|c|c|c|c|c|c|c|c|c|c|c|c|c|}
\hline Cerita & \multicolumn{15}{|c|}{ Tahap } \\
\hline & 1 & 2 & 3 & 4 & 5 & 6 & 7 & 8 & 9 & 10 & 11 & 12 & & & \\
\hline $\mathrm{I}$ & & & & 4 & 3 & 2 & $\mathrm{M}$ & 3 & 4 & $\mathrm{M}$ & 6 & $\mathrm{~A}$ & $5 \mathrm{~A}$ & 3 & $5 \mathrm{~A}$ \\
\hline II & & & & 3 & 4 & $\mathrm{~A}$ & 4 & 6 & $\mathrm{M}$ & 3 & 4 & 3 & 4 & $5 \mathrm{~A}$ & $5 \mathrm{~A}$ \\
\hline II & & & & 4 & 4 & 2 & 4 & $\mathrm{M}$ & $5 \mathrm{~A}$ & 3 & 3 & $5 B$ & $5 \mathrm{~A}$ & 4 & 3 \\
\hline
\end{tabular}

Memasukkan keempat urutan tersebut sesuai dengan bobot yang telah ditentukan ke dalam lembar skoring data subjek. Misalnya subjek 1 pada cerita Obat (Heinz and Drug) memilih pernyataan penting pertama nomor 8 berada pada tahap 6 , penting kedua nomor 10 berada pada tahap 5A, penting ketiga nomor 12 berada pada tahap 5A, dan penting keempat nomor 6 berada pada tahap 4. Bobot penilaian penting pertama sampai keempat bernilai 4 sampai 1. Apabila dimasukkan ke dalam lembar skoring hasilnya sebagai berikut :

Tabel 3

Lembar Skoring

\begin{tabular}{|c|c|c|c|c|c|c|c|c|c|}
\hline Cerita & & & & & ahap & & & & \\
\hline & 2 & 3 & 4 & $5 \mathrm{~A}$ & $5 B$ & 6 & A & $\mathrm{M}$ & $\mathrm{P}$ \\
\hline I & & & & & 1 & 3,2 & & 4 & \\
\hline II & & & & & & & & & \\
\hline II & & & & & & & & & \\
\hline Total & & & & & & & & & \\
\hline
\end{tabular}

Menghitung nilai P yaitu dengan menjumlahkan nilai total 5A, 5B, dan 6 .

Dalam penggunaan DIT di Indonesia, DIT telah diadaptasi dan diuji reliabilitasnya oleh Martani (dalam Nugroho, 2014) dengan nilai korelasi yang bergerak dari 0,255-0,410 yang menunjukkan bahwa alat ukur DIT aitem-aitemnya homogen untuk digunakan di Indonesia. Pengujian reliabilitas dan validitas DIT versi singkat juga dilakukan oleh Menanti (dalam Nugroho, 2014) pada siswa SMA dan menghasilkan $\alpha=0,78$ dan didapatkan hasil uji homogenitas aitem yang menunjukkan rentang antara $0,38-0,67$. Uji reliabilitas juga dilakukan oleh Nurhidayah (2001) kepada siswa SMA dengan hasil nilai $\alpha=0,709$.

Teknik analisis data yang digunakan untuk menentukan ada tidaknya hubungan antara penalaran moral dengan kecurangan akademik yaitu analisis korelasi Spearman Rho. Penggunaan analisis korelasi Spearman Rho untuk uji hipotesis penelitian karena distribusi data variabel penalaran moral tidak normal. Perhitungan menggunakan bantuan program SPSS for windows versi 16.0 . 


\section{HASIL DAN PEMBAHASAN}

Dalam penelitian ini, pada skala penalaran moral didapatkan nilai maksimum sebesar 25 , minimum sebesar 0, mean sebesar 10,21 dan standar deviasi sebesar 5,25.

Tabel 4.

Kategori Skor Penalaran Moral

\begin{tabular}{|c|c|c|c|c|c|}
\hline Kategori & Interval & Frekuensi & $\%$ & Mean & $\begin{array}{l}\text { Standar } \\
\text { Deviasi }\end{array}$ \\
\hline Sangat Tinggi & $20 \leq x<25$ & 7 & $6 \%$ & \multirow{5}{*}{10,21} & \multirow{5}{*}{5,25} \\
\hline Tinggi & $15 \leq x<20$ & 5 & $5 \%$ & & \\
\hline Sedang & $10 \leq x<15$ & 35 & $32 \%$ & & \\
\hline Rendah & $5 \leq x<10$ & 42 & $39 \%$ & & \\
\hline Sangat Rendah & $0 \leq x<5$ & 20 & $18 \%$ & & \\
\hline
\end{tabular}

Dari tabel diatas dapat dilihat bahwa kategori sangat tinggi memiliki persentase sebesar $6 \%$, kategori tinggi memiliki persentase 5\%, kategori sedang memiliki persentase sebesar $32 \%$, kategori rendah memiliki persentase sebesar 39\%, dan kategori sangat rendah memiliki persentase sebesar 18\%. Jadi sebagian besar mahasiswa (39 \%) mahasiswa S1 Psikologi Universitas Kristen Satya Wacana angkatan 2014 memiliki penalaran moral yang masuk ke dalam kategori rendah

Tabel 5.

Kategori Skor Kecurangan Akademik

\begin{tabular}{llccrc}
\hline Kategori & Interval & Frekuensi & $\%$ & Mean & $\begin{array}{c}\text { Standar } \\
\text { Deviasi }\end{array}$ \\
\hline Sangat Tinggi & $98,6 \leq \mathrm{x}<116$ & 0 & & \\
\cline { 1 - 4 } Tinggi & $81,2 \leq \mathrm{x}<98,6$ & 3 & $0 \%$ & & \\
\cline { 1 - 4 } Sedang & $63,8 \leq \mathrm{x}<81,2$ & 23 & $21 \%, 59$ & \multirow{2}{*}{11,43} \\
\cline { 1 - 4 } Rendah & $46,4 \leq \mathrm{x}<63,8$ & 60 & $55 \%$ & & \\
\cline { 1 - 4 } Sangat Rendah & $29 \leq \mathrm{x}<46,4$ & 23 & $21 \%$ & & \\
\hline
\end{tabular}

Dari tabel diatas dapat dilihat bahwa kategori sangat tinggi memiliki persentase sebesar $0 \%$, kategori tinggi memiliki persentase 3\%, kategori sedang memiliki persentase sebesar $21 \%$, kategori rendah memiliki persentase sebesar 55\%, dan kategori sangart rendah memiliki persentase sebesar 21\%. Jadi sebagian besar mahasiswa (55 \%) mahasiswa S1 Psikologi Universitas Kristen Satya Wacana angkatan 2014 menunjukkan perilaku kecurangan akademik yang masuk ke dalam kategori rendah 
Tabel 6.

Uji Normalitas

\begin{tabular}{llll}
\hline \multicolumn{4}{l}{ One-Sample Kolmogorov-Smirnov Test } \\
\hline & & Kecurangan Akademik & Penalaran moral \\
\hline $\mathrm{N}$ & 109 & 109 \\
\hline \multirow{2}{*}{ Normal Parameters } & a & & \\
\cline { 2 - 4 } & Mean & 55.59 & 10.21 \\
\hline \multirow{2}{*}{$\begin{array}{l}\text { Most Extreme } \\
\text { Differences }\end{array}$} & Absolute & .077 & 5.253 \\
\cline { 2 - 4 } & Positive & .071 & .137 \\
\cline { 2 - 4 } & Negative & -.077 & .137 \\
\hline Kolmogorov-Smirnov Z & .799 & -.060 \\
\hline \multicolumn{2}{l}{ Asymp. Sig. (2-tailed) } & .546 & 1.434 \\
\hline
\end{tabular}

Hasil menunjukkan untuk variabel kecurangan akademik nilai K-S-Z sebesar 0,799 dengan nilai sign. $=0,546(\mathrm{p}>0,05)$, berarti data berdistribusi normal. Untuk variabel penalaran moral memiliki nilai K-S-Z sebesar 1,434 dengan nilai sign. $=0,033(\mathrm{p}<0,05)$. Berarti data penalaran moral tidak berdistribusi normal maka analisis data untuk uji hipotesis menggunakan teknik statistik non parametris (Sugiyono, 2005).

Tabel 7.

Uji Linieritas

\begin{tabular}{|c|c|c|c|c|c|c|c|}
\hline \multicolumn{8}{|l|}{ ANOVA Table } \\
\hline & & & $\begin{array}{l}\text { Sum of } \\
\text { Squares }\end{array}$ & df & $\begin{array}{l}\text { Mean } \\
\text { Square }\end{array}$ & $\mathrm{F}$ & Sig. \\
\hline \multirow{5}{*}{$\begin{array}{l}\text { Kecurangan Akademik * } \\
\text { Penalaran Moral }\end{array}$} & \multirow{3}{*}{$\begin{array}{l}\text { Between } \\
\text { Groups }\end{array}$} & (Combined) & 3534.435 & 21 & 168.306 & 1.383 & .149 \\
\hline & & Linearity & 113.854 & 1 & 113.854 & .936 & .336 \\
\hline & & $\begin{array}{l}\text { Deviation from } \\
\text { Linearity }\end{array}$ & 3420.581 & 20 & 171.029 & 1.406 & .142 \\
\hline & \multicolumn{2}{|c|}{ Within Groups } & 10583.987 & 87 & 121.655 & & \\
\hline & \multicolumn{2}{|c|}{ Total } & 14118.422 & 108 & & & \\
\hline
\end{tabular}

Berdasarkan tabel 7, dapat dilihat dari hasil uji linieritas yaitu nilai $\mathrm{F}$ beda sebesar 1.406 dan nilai signifikansi sebesar $0,142(\mathrm{p}>0,05)$, berarti hubungan antara kedua variabel tersebut linier.

Hasil uji korelasi antara penalaran moral dan kecurangan akademik, dapat dilihat pada tabel berikut: 
Tabel 8.

Uji Korelasi

\begin{tabular}{lllll}
\hline Correlations & & & \\
\hline \multirow{2}{*}{ Spearman's rho } & $\begin{array}{l}\text { Kecurangan } \\
\text { Akademik }\end{array}$ & $\begin{array}{l}\text { Kecurangan } \\
\text { Akademik }\end{array}$ & $\begin{array}{l}\text { Penalaran } \\
\text { Moral }\end{array}$ \\
\cline { 2 - 5 } & Penalaran Moral & $\begin{array}{l}\text { Correlation } \\
\text { Coefficient }\end{array}$ & 1.000 & .003 \\
\cline { 2 - 4 } & \begin{tabular}{llll} 
Sig. (1-tailed) \\
\cline { 2 - 4 }
\end{tabular} & $\begin{array}{l}\text { Correlation } \\
\text { Coefficient }\end{array}$ & .003 & .489 \\
\cline { 2 - 4 } & Sig. (1-tailed) & .489 & 109 \\
\cline { 2 - 4 } & $\mathrm{N}$ & 109 & 1.000 \\
\hline
\end{tabular}

Hasil uji korelasi antara penalaran moral dengan perilaku kecurangan akademik menggunakan Spearman's Rho menunjukkan nilai r sebesar 0,003 dengan nilai signifikansi sebesar 0,489 $(\mathrm{P}>0,05)$, yang bermakna tidak ada hubungan antara penalaran moral dengan perilaku kecurangan akademik pada mahasiswa Psikologi UKSW angkatan 2014. Ini menunjukkan bahwa hipotesis penelitian ditolak.

Hasil penelitian ini mendukung penelitian sebelumnya dari Khoridatul (2014) yang menyatakan hasil tidak ada korelasi antara penalaran moral dengan perilaku kecurangan mencontek. Juga penelitian dari West, Ravenscroft dan Shrader (2004) yang menunjukkan hasil bahwa tidak ada hubungan antara penalaran moral dan kejujuran. Namun hasil penelitian ini bertentangan dengan penelitian Veronikha, Yusuf dan Machmuroch (2013) yang menghasilkan temuan bahwa ada hubungan yang negatif antara moral judgment maturity dengan perilaku mencontek.

Peneliti mencoba mencari beberapa kemungkinan mengapa hipotesis dalam penelitian ini ditolak dengan kembali mewawancarai partisipan penelitian. Berdasarkan hasil wawancara, antara lain diketahui bahwa sejumlah partisipan sebenarnya tidak ingin melakukan kecurangan akademik meskipun ada kesempatan. Namun, partisipan akan melakukan kecurangan akademik ketika situasi benar-benar mendesak dan merasa putus asa selama proses pengerjaan Tugas Akhir. Seperti misalnya saat partisipan tidak memperoleh jurnal pendukung, ataupun literatur yang diperlukan dalam pengerjaan tugas akhir, mereka akan melakukan copy paste. Salah satu mahasiswa menyatakan kepada penulis sebagai berikut:

"Dosen pembimbing minta saya mencari jurnal/buku aslinya yang memuat tentang definisi dan aspek-aspek variabel penelitianku untuk memastikan bahwa definisi dan aspek-aspeknya 
memang betul. Tapi sudah satu bulan saya belum mendapatkan. Ya sudah..trus saya copy paste dari skripsi kakak kelas, untungnya dosen tidak minta untuk menunjukkan jurnalnya”

Dari analisis deskriptif dapat dilaporkan bahwa perilaku kecurangan akademik mahasiswa Psikologi UKSW angkatan 2014 tergolong rendah yaitu sebesar 55\%. Rendahnya kecurangan akademik pada mahasiswa Psikologi UKSW angkatan 2014 juga dikarenakan pembaharuan sistem dan peraturan penyusunan Tugas Akhir di Fakultas Psikologi UKSW. Pembaharuan sistem ini mengharuskan mahasiswa untuk menghadiri bimbingan skripsi secara rutin dibawah pengawasan dari dosen pembimbing setidaknya satu minggu sekali dan adanya kuota maksimal jumlah mahasiswa bimbingan bagi setiap dosen. Partisipan beranggapan bahwa feedback selama proses bimbingan yang intens, cermat, dan mendalam membuat mahasiswa enggan melakukan kecurangan akademik. Sistem dan aturan tersebut menjadi salah satu faktor selain penalaran moral yang memengaruhi kecurangan akademik pada mahasiswa Psikologi UKSW angkatan 2014. Hal ini sesuai dengan pernyataan yang diungkapkan oleh McCabe, Trevino, dan Butterfield (2001) bahwa peraturan yang ada di lembaga pendidikan turut menjadi faktor determinan perilaku ketidakjujuran akademik. Sagoro (2013) mengatakan bahwa pencegahan kecurangan akademik dapat berhasil jika seluruh elemen dalam sistem pendidikan (mahasiswa, dosen, dan lembaga) dalam hal ini jurusan, fakultas, dan universitas mampu bersinergi secara baik. Adanya kerjasama dan komitmen antara mahasiswa, dosen, dan lembaga diharapkan dapat mencegah dan menghilangkan budaya curang di dunia pendidikan. Selanjutnya wawancara yang dilakukan oleh penulis juga mengungkapkan adanya faktor lain yang mungkin lebih memengaruhi kecurangan akademik yang dilakukan mahasiswa yaitu konformitas teman sebaya. Beberapa partisipan menyampaikan bahwa mereka melakukan kecurangan akademik karena melihat teman-teman seangkatan juga melakukan kecurangan akademik sehingga menganggap hal tersebut adalah hal yang wajar. Bentuk kecurangan yang banyak dilakukan seperti copy-paste ketika mengerjakan Tugas Akhir, memalsukan data kuantitatif, dan melakukan manipulasi wawancara. Bahkan beberapa teman seangkatan mendukung dan menyarankan partisipan untuk melakukan kecurangan akademik supaya cepat lulus. Seorang mahasiswa mengaku bahwa ia memanipulasi data agar aitem-aitem kuesionernya tidak banyak yang gugur dan teman-temannya pun banyak melakukan hal tersebut.

"Sebenarnya saya nggak mau curang karena dosen pembimbing selalu mengingatkan. Tapi kok aitem-aitemku banyak yang gugur...ada separuh lebih. Terus ada teman bilang untuk 
mengganti beberapa skor agar aitem yang gugur tidak banyak......Temanku juga bilang beberapa teman-teman lain juga begitu.....”

Hal ini sesuai dengan pernyataan yang dikemukakan oleh McCabe (2001) yang mengungkapkan bahwa faktor kontekstual yaitu konformitas teman sebaya dapat memengaruhi adanya kecurangan akademik. Hasil wawancara ini juga didukung penelitian oleh Raharjo (2015) yang menyatakan bahwa konformitas teman sebaya berkorelasi positif dengan perilaku menyontek pada Siswa XI Jurusan Teknik Pengelasan SMK N 1 Sedayu. Konformitas merupakan perilaku ingin sama dengan teman/kelompoknya agar tidak mendapat tekanan atau celaan dari teman sebayanya (Santrock, 2002), dan hal ini bisa terjadi pada kelompok umur remaja termasuk mahasiswa karena pada tahapan ini remaja memiliki keinginan/kecenderungan untuk sama dengan teman sebayanya, baik untuk perilaku yang positif maupun negatif.

Dari segi metodologis, ditolaknya hipotesis penelitian ini kemunkginan juga dapat disebabkan terjadinya faking good dalam menjawab skala kecurangan akademik. Jadi mahasiswa yang mengisi skala kecurangan akademik cenderung mengisi yang tidak sesungguhnya karena sebenarnya mahasiswa tahu bahwa perilaku tersebut merupakan perilaku yang tidak terpuji. Hal ini sesuai dengan pendapat Azwar (2012) bahwa responden cenderung memilih alternatif jawaban yang diharapkan atau yang sesuai dengan norma masyarakat pada aitem-aitem yang mengandung social desirability. Sebaliknya pada skala penalaran moral, kemungkinan responden menjawab sudah sesuai dengan kondisinya ( memiliki penalaran yang baik), namun penalaran merupakan aspek kognitif yang belum tentu dimanifestasikan dalam bentuk perilaku karena perilaku dipengaruhi oleh berbagai faktor.

Sementara itu hasil analisis deskriptif menghasilkan temuan bahwa penalaran moral pada mahasiswa S1Psikologi UKSW angkatan 2014 berada pada kategori rendah sebesar 39\%, kategori sangat tinggi memiliki presentase sebesar 6\%, kategori tinggi memiliki presentase 5\%, kategori sedang memiliki presentase sebesar 32\%, dan sisanya masuk ke dalam kategori sangat rendah dengan presentase sebesar 18\%. Kemudian hasil analisis deskriptif kecurangan akademik pada mahasiswa Psikologi UKSW angkatan 2014 berada pada kategori rendah sebesar 55\% sedangkan $21 \%$ nya masuk dalam kategori sedang dan sangat rendah, sementara sisanya $3 \%$ tergolong sangat tinggi. 


\section{SIMPULAN}

Berdasarkan hasil penelitian, maka dapat disimpulkan bahwa tidak ada hubungan antara penalaran moral dan kecurangan akademik pada mahasiswa S1 Psikologi UKSW angkatan 2014.

Berdasarakan hasil penelitian serta mengingat masih banyaknya keterbatasan dalam penelitian ini, maka peneliti memiliki beberapa saran sebagai berikut:

Bagi Fakultas

Untuk mengembangkan sistem dan aturan penyusunan Tugas Akhir yang sistematis dan terstandar. Sistem dan aturan ini meliputi sanksi yang tegas bagi para mahasiwa yang melakukan tindakan kecurangan akademik serta pengawasan yang ketat oleh pihak fakultas dalam pelaksanaan Tugas Akhir. Selain itu fakultas hendaknya menyediakan fasilitas screening pendeteksian plagiarisme bagi para mahasiswanya.

Bagi Mahasiswa

Meningkatkan kesadaran akan kedisiplinan dan kode etik, membentuk kelompok belajar untuk mengatasi kesulitan yang dihadapi.

Bagi Peneliti Selanjutnya

Skala kecurangan akademik yang digunakan rentan social desirebility sehingga menyebabkan partisipan cenderung melakukan faking pada beberapa item. Begitu juga dengan bentuk skala penalaran moral yang cukup rumit dalam pengisiannya sehingga banyak dikeluhkan oleh partisipan sehingga bagi peneliti selanjurtnya harus lebih memperhatikan bentuk skala yang digunakan dan mempertimbangkan faktor-faktor lain selain penalaran moral untuk diteliti.

\section{DAFTAR PUSTAKA}

Anderman, E. M., \& Murdock, T. B. (2007). Psychology of academic cheating. Burlington: Elsevier Inc.

Azwar, S. (2000). Penyusunan skala psikologi. Yogyakarta: Pustaka Pelajar.

Azwar, S. (2012). Metode penelitian. Yogyakarta: Pustaka Pelajar.

Budinugroho, B (2006). Penalaran moral dan kecurangan akademik mahasiswa. Skripsi. Fakultas Psikologi. Surabaya: Universitas Surabaya.

Belanger, C.H., Leonard, V.M., \& LeBrasseur, R. (2012). Moral reasoning, academic dishonesty, and business students. International Journal of Higher Education, 1(1), 7289. 
Broeckelman, M., \& Pollock, T. (2006). An honest look at academic dishonesty at ohio university. 1-92

Davis, S. F., Drinan, P. F., \& Gallant, T. B. (2009). Cheating in school: what we know andwhat we can do. Chicester: WileyBlackwell.

Gehring, D. D., \& Pavela, G. (1994). Issues and perspectives on academic integrity. Washington, DC: National Association of Student Personnel Administrators.

Khoridatul, Afroh. (2014). Hubungan antara penalaran moral dengan perilaku menyontek pada siswa di Madrasah Tsanawiyah Negeri Gondowulung Bantul.Skripsi.. Yogyakarta: Fakultas Ilmu Sosial dan Humaniora,Universitas Islam Negeri.

McCabe, D. L., Trevino, L.K., \& Butterfield, K. (2001). Cheating in academic institutions: a decade of research. Ethics \& Behavior, 11(3), 219-232.

McCabe, D. L.( 2005). Cheating among college and university students. A North American Perspective. International Journal of Educational Integrity, 1(1), 1-11.

Murphy, K. R., \& Davidshofer, C.O. (1994). Psychological testing: principles and applications. New Jersey: Prentice Hall.

Ningsih, R., \& Pratikto, H. (2012). Konsep diri, kematangan emosi dan kecenderungan menyontek, Jurnal Psikologi, 7(2), 594-604.

Nugroho, R. D. (2014). Hubungan antara penalaran moral siswa sma dengan asal sekolah,pengasuhan orangtua, dan iklim sekolah. Skripsi. Jakarta: Fakultas Psikologi Universitas Indonesia.

Nurhidayah, S. (2001). Perkembangan moral pada siswa SMU umum dan SMU berasrama di Jakarta. Tesis. Jakarta: Fakultas Psikologi Universitas Indonesia.

Nursalam., Bani,S., \& Munirah (2013). Bentuk kecurangan akademik (academic cheating) mahasiswa PGMI Fakultas Tarbiyah dan Keguruan UIN Alauddin Makassar. Lentera Pendidikan, 16(2), 127-138.

Putri, N., \& Dewi, N. (2018). Peran sistem Pendidikan Tinggi dalam melunturkan karakter jujur mahasiswa. Indigenous Jurnal ILmiah Psikologi, 3(1), 31-46.

Raharjo, P. G. (2015) Pengaruh kepercayaan diri dan konformitas teman sebaya terhadap perilaku menyontek siswa kelas xi jurusan teknik pengelasan SMKN 1 Sedayu tahun ajaran 2014/2015. .Skripsi. Yogyakarta: Prodi Psikologi UniversitasNegeri Yogyakarta.

Rest, J., Thoma, S. J., Narvaez, D., \& Bebeau, M.J. (1997). Alchemy and beyond indexing the defining issues test. Journal of Educational Psychology, 89(3), 498-507 
Rettinger, D. A., \& Jordan, A. E. (2005). The relations among religion, motivation, and college cheating: a naturalexperiment. Ethic \& Behavior, 15(2), 107-129.

Santrock, J. W. (2002). A topical approach to life-span development, international ed. Boston : Mc Graw Hill.

Sagoro, M. A. (2013). Pensinergian mahasiswa, dosen, dan lembaga dalam pencegahan kecurangan akademik mahasiswa akuntansi. Jurnal Pendidikan Akuntansi Indonesia, $6(2), 54-57$

Soetjiningsih, C.H., (2017). Perkembangan anak. Jakarta: Prenada Media.

Sugiyono, (2005). Statistika untuk penelitian. Bandung: CV Alfabeta

Veronika, M. T., Yusuf, M., \& Machmuroh (2013). Hubungan antara moral judgment maturity dengan perilaku menyontek pada siswa kelas x SMA Negeri 8 Surakarta. Jurnal Ilmiah Psikologi Candrajiwa, 2(4), 131-143.

West., Ravenscroft, S., \& Shrader, C. (2004). Cheating and moral judgment in the college classroom: a natural experiment. Journal of Business Ethics, 54, 173-183. 